\title{
The effect of natural organic matter on the adsorption of mercury to bacterial cells
}

\author{
Sarrah Dunham-Cheatham ${ }^{1 \ddagger}$, Bhoopesh Mishra $^{2}$, Satish Myneni ${ }^{3}$, and Jeremy B. Fein ${ }^{1}$ \\ ${ }^{1}$ Department of Civil and Environmental Engineering and Earth Sciences, University of Notre \\ Dame, Notre Dame, IN 46556, USA \\ ${ }^{2}$ Department of Physics, Illinois Institute of Technology, Chicago, Illinois 60616, USA \\ ${ }^{3}$ Department of Geosciences, Princeton University, Princeton, NJ 08544, USA
}

\begin{abstract}
We investigated the ability of non-metabolizing Bacillus subtilis, Shewanella oneidensis MR-1, and Geobacter sulfurreducens bacterial species to adsorb mercury in the absence and presence of Suwanee River fulvic acid (FA). Bulk adsorption and X-ray absorption spectroscopy (XAS) experiments were conducted at three $\mathrm{pH}$ conditions, and the results indicate that the presence of FA decreases the extent of $\mathrm{Hg}$ adsorption to biomass under all of the $\mathrm{pH}$ conditions studied. Hg XAS results show that the presence of FA does not alter the binding environment of $\mathrm{Hg}$ adsorbed onto the biomass regardless of $\mathrm{pH}$ or FA concentration, indicating that ternary bacteria-Hg-FA complexes do not form to an appreciable extent under the experimental conditions, and that $\mathrm{Hg}$ binding on the bacteria is dominated by sulfhydryl binding. We used the experimental results to calculate apparent partition coefficients, $\mathrm{K}_{\mathrm{d}}$, for $\mathrm{Hg}$ under each experimental condition. The calculations yield similar coefficients for $\mathrm{Hg}$ onto each of the bacterial species studies, suggesting there is no significant difference in $\mathrm{Hg}$ partitioning between the three bacterial species. The calculations also indicate similar coefficients for $\mathrm{Hg}$-bacteria and Hg-FA complexes. S XAS measurements confirm the presence of sulfhydryl sites on both the FA and bacterial cells, and demonstrate the presence of a wide range of $\mathrm{S}$ moieties on the FA in contrast to the bacterial biomass, whose $\mathrm{S}$ sites are dominated by thiols. Our results suggest that

\footnotetext{
† Corresponding author: dr.smdcheatham@gmail.com 
although FA can compete with bacterial binding sites for aqueous $\mathrm{Hg}$, because of the relatively similar partition coefficients for the types of sorbents, the competition is not dominated by either bacteria or FA unless the concentration of one type of site greatly exceeds that of the other.

\section{Introduction}

Heavy metals, such as $\mathrm{Hg}$, adsorb to proton-active functional groups on bacterial cell envelopes (e.g., Beveridge and Murray, 1976; Fortin and Beveridge, 1997; Daughney et al., 2002; Fein, 2006; Kenney and Fein, 2011), affecting the speciation and distribution of these metals in environmental systems. Recent studies (e.g., Guiné et al., 2006; Mishra et al. 2007; 2009; 2010; 2011; Joe-Wong et al., 2012; Pokrovsky et al., 2012; Song et al., 2012; Colombo et al., 2013; Yu et al., 2014) have shown that at least some bacterial cell envelopes contain protonactive sulfhydryl functional groups. Because Hg binds readily and strongly to sulfur compounds (Compeau and Bartha, 1987; Winfrey and Rudd, 1990; Benoit et al., 1999), bacterial adsorption of $\mathrm{Hg}$ may dramatically affect the distribution, transport and fate of $\mathrm{Hg}$ in geologic systems.

Natural organic matter (NOM) is present in nearly every near-surface geologic system, and complexation reactions between metals and NOM can dramatically change the behavior of the metals in the environment (McDowell, 2003; Ravichandran, 2004). NOM molecules contain a range of functional group types, including carboxyl, phenol, amino, and sulfhydryl groups, that have the potential to create highly stable complexes with metal ions across the $\mathrm{pH}$ scale (Ephraim, 1992; Ravichandran et al., 1999; Drexel et al., 2002; Haitzer et al., 2002; Croué et al., 2003; Ravichandran, 2004). Hg binds strongly to the sulfhydryl groups present within the NOM structure (Dong et al., 2011; Muresan et al., 2011). The relative thermodynamic stabilities of $\mathrm{Hg}$ NOM and Hg-bacteria complexes are not well known. Depending on these relative stabilities, the 
formation of metal-NOM complexes may decrease adsorption of $\mathrm{Hg}$ to bacteria cell envelopes due to a competitive ligand effect, or under certain conditions may increase adsorption of $\mathrm{Hg}$ to bacteria due to ternary complexation with $\mathrm{NOM}$. For example, investigating $\mathrm{Pb}, \mathrm{Cu}$, and $\mathrm{Ni}$ separately, Borrok et al. (2007) found that ternary metal-FA-bacteria complexes form, and that the importance of the complexes is strongly affected by $\mathrm{pH}$. Conversely, Wightman and Fein (2001) found that the presence of NOM decreases the amount of Cd adsorbed to bacteria under mid- and high-pH conditions, and that the presence of $\mathrm{Cd}$ does not affect the adsorption of NOM to bacteria, suggesting that ternary complexes do not occur. No studies have been conducted to date to determine the effects of NOM on $\mathrm{Hg}$ binding to bacteria. However, because $\mathrm{Hg}$ forms strong complexes both with cell envelopes (Daughney et al., 2002; Mishra et al., 2011; DunhamCheatham et al., 2014) and NOM (Loux et al., 1998; Ravichandran, 2004; Skyllberg et al., 2006), it is likely that significant changes to $\mathrm{Hg}$ adsorption behavior occur in the presence of NOM.

In this study, we used bulk adsorption and Hg X-ray absorption spectroscopy (XAS) experiments, conducted as a function of $\mathrm{pH}$ and FA concentration, using intact non-metabolizing bacterial cells to study $\mathrm{Hg}$ binding onto three different bacterial species and to compare the ability of bacteria to adsorb mercury in the presence and absence of a fulvic acid (FA). We used the experimental results to calculate apparent partition coefficients, $\mathrm{K}_{\mathrm{d}}$, for $\mathrm{Hg}$-bacteria and $\mathrm{Hg}$ FA complexes. This study examined both Gram-positive and Gram-negative bacterial species in order to determine if cell envelope structure affects the binding reactions, and one species was a $\mathrm{Hg}$ methylator, which we examined in order to determine if the extent or nature of $\mathrm{Hg}$ binding onto that species differed from that exhibited by the non-methylators. 


\section{Methods}

\section{Experimental methods}

\section{Bacterial growth and washing procedure}

Bacillus subtilis (a Gram-positive aerobic soil species) and Shewanella oneidensis MR-1 (a Gram-negative facultative anaerobic species) cells were cultured and prepared following the procedures outlined in Borrok et al. (2007). Briefly, cells were maintained on agar plates consisting of trypticase soy agar with $0.5 \%$ yeast extract added. Cells for all experiments were grown by first inoculating a test-tube containing $3 \mathrm{~mL}$ of trypticase soy broth with $0.5 \%$ yeast extract, and incubating it for $24 \mathrm{~h}$ at $32{ }^{\circ} \mathrm{C}$. The $3 \mathrm{~mL}$ bacterial suspension was then transferred to $1 \mathrm{~L}$ of trypticase soy broth with $0.5 \%$ yeast extract for another $24 \mathrm{~h}$ on an incubator shaker table at $32{ }^{\circ} \mathrm{C}$. Cells were pelleted by centrifugation at $8100 \mathrm{~g}$ for $5 \mathrm{~min}$, and rinsed 5 times with $0.1 \mathrm{M}$ $\mathrm{NaClO}_{4}$

Geobacter sulfurreducens (a Gram-negative species capable of $\mathrm{Hg}$ methylation) cells were cultured and prepared using a different procedure than detailed above. Cells were maintained in $50 \mathrm{~mL}$ of anaerobic freshwater basal media (ATCC 51573) at $32{ }^{\circ} \mathrm{C}$ (Lovely and Phillips, 1988). Cells for all experiments were grown by first inoculating an anaerobic serum bottle containing $50 \mathrm{~mL}$ of freshwater basal media, and incubating it for 5 days at $32{ }^{\circ} \mathrm{C}$. Cells were pelleted by centrifugation at $8100 \mathrm{~g}$ for 5 minutes, and rinsed 5 times with $0.1 \mathrm{M} \mathrm{NaClO}_{4}$ stripped of dissolved oxygen by bubbling a $85 \% / 5 \% / 10 \% \mathrm{~N}_{2} / \mathrm{H}_{2} / \mathrm{CO}_{2}$ gas mixture through it for 30 minutes. After washing, each of the three types of bacteria was then pelleted by centrifugation at $8100 \mathrm{~g}$ for 60 minutes to remove excess water in order to determine the wet mass so that suspensions of known bacterial concentration could be created. All bacterial concentrations in this study are given in terms of gm wet biomass per liter. Bacterial cells were harvested during 
stationary phase, and all adsorption experiments were performed under oxic, non-metabolizing, electron donor-free conditions.

\section{Adsorption experiments}

To prepare experiments, aqueous $\mathrm{Hg}$, NOM, and suspended bacteria stock solutions were mixed in different proportions to achieve the desired final concentrations for each experiment. The experiments were conducted in sets with constant $\mathrm{pH}$ (at $\mathrm{pH} 4.0 \pm 0.1,6.0 \pm 0.1$, or $8.0 \pm$

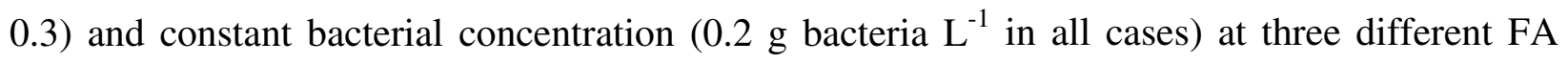
concentrations $\left(0,25\right.$, or $\left.50 \mathrm{mg} \mathrm{L}^{-1}\right)$, with $\mathrm{Hg} \log$ molalities ranging from -6.30 to -5.00 (0.1 to $\left.2.0 \mathrm{mg} \mathrm{L}^{-1}\right)$.

FA stock solutions were prepared in Teflon bottles by dissolving dried, powdered International Humic Substances Society Suwannee River FA Standard I in a $0.1 \mathrm{M} \mathrm{NaClO}_{4}$ buffer solution to achieve the desired final FA concentration for each experiment. A known mass of wet biomass was then suspended in the FA stock solution, and the $\mathrm{pH}$ of the FA-bacteria parent solution was immediately adjusted to the experimental $\mathrm{pH}$ using $0.2 \mathrm{M} \mathrm{HNO}_{3}$ and/or $\mathrm{NaOH}$. To prepare experimental solutions, aliquots of the FA-bacteria parent solution were added gravimetrically to Teflon reaction vessels, followed by a small aliquot of commerciallysupplied 1,000 $\mathrm{mg} \mathrm{L}^{-1} \mathrm{Hg}$ aqueous standard to achieve the desired final $\mathrm{Hg}$ concentration. The $\mathrm{pH}$ of each suspension was again adjusted immediately to the experimental $\mathrm{pH}$. The vessels were placed on an end-over-end rotator to agitate the suspensions for the duration of the experiment (2 $\mathrm{h}$ for B. subtilis and G. sulfurreducens and $3 \mathrm{~h}$ for S. oneidensis MR-1, as determined by initial kinetics experiments (results not shown)). The $\mathrm{pH}$ of the suspensions was monitored and adjusted every 15 minutes throughout the duration of the experiment, except during the last 30 
minutes, when the suspensions were undisturbed. At the completion of each experiment, the $\mathrm{pH}$ of the suspensions was measured and the experimental suspensions were centrifuged at $8100 \mathrm{~g}$ for 5 minutes. The aqueous phase was collected for $\mathrm{Hg}$ analysis by inductively-coupled plasma optical emission spectroscopy (ICP-OES), and the solid phase of some of the runs was collected for XAS analyses. Duplicate experiments were performed for each experimental condition.

\section{ICP-OES measurements}

ICP-OES standards were prepared gravimetrically by diluting a commercially-supplied 1,000 $\mathrm{mg} \mathrm{L}^{-1} \mathrm{Hg}$ aqueous standard with $\mathrm{pH}$-adjusted 0,25 , or $50 \mathrm{mg} \mathrm{L}^{-1}$ FA stock solution made in $0.1 \mathrm{M} \mathrm{NaClO}_{4}$ so that the $\mathrm{pH}$, ionic strength, and FA concentration of the standards closely matched that of the samples. We found significant interference when standards and samples were not closely matched in this way. The log molality of the $\mathrm{Hg}$ standards ranged from -6.60 to -5.00 . The standards and samples were all stored in Teflon containers and analyzed with a Perkin Elmer 2000DV ICP-OES at wavelength $253.652 \mathrm{~nm}$ within 1 day of collection. The set of standards was analyzed before and after all of the samples were analyzed, as well as after every 15 samples, to check for machine drift. Analytical uncertainty, as determined by repeat analyses of the standards, was $\pm 2.8 \%$ for the $0 \mathrm{mg} \mathrm{L}^{-1} \mathrm{FA}$ samples, $\pm 7.7 \%$ for the $25 \mathrm{mg} \mathrm{L}^{-1} \mathrm{FA}$ samples, and $\pm 9.5 \%$ for the $50 \mathrm{mg} \mathrm{L}^{-1} \mathrm{FA}$ samples. Neither standards nor samples were acidified prior to analysis. FA concentration strongly affected system performance and signal strength, likely due to spectral interferences caused by the FA molecule. Abiotic control experiments were conducted under conditions identical to the biotic experiments except without biomass present to determine the extent of $\mathrm{Hg}$ loss due to adsorption onto the experimental apparatus as well as any 
interference caused by the presence of FA during the ICP-OES analysis. The extent of $\mathrm{Hg}$ removal in these controls did not vary systematically with $\mathrm{pH}$ and was below $10 \%$ adsorption.

\section{XAS measurements}

Hg LIII-edge X-ray absorption near edge structure (XANES) and extended X-ray absorption fine-structure spectroscopy (EXAFS) measurements were performed at the MRCAT sector 10-ID beamline (Segre et al., 2000), Advanced Photon Source, at Argonne National Laboratory. The continuous-scanning mode of the undulator was used with a step size of $0.5 \mathrm{eV}$ and an integration time of $0.1 \mathrm{sec}$ per point to decrease the radiation exposure during a single scan. Additionally, measurements were made at different spots on the samples to further decrease the exposure time. Hg XAS measurements were collected as described in Mishra et al. (2011).

Cinnabar (red $\mathrm{HgS}$ ) and mercuric acetate crystalline powder standards were measured and used to calibrate the theoretical calculations against experimental data. Data collected from the powder standards were analyzed to obtain the S02 parameter, where S02 is the value of the passive electron reduction factor used to account for many-body effects in EXAFS. By fixing the values of $\mathrm{S}$ and $\mathrm{O}$ atoms to 2 in the cinnabar and mercuric acetate standards, we obtained S02 values of $1.02 \pm 0.05$ and $0.98 \pm 0.03$, respectively. Hence, we chose to set the value of S02 $=1.0$ for all samples. Fitting of the powder standards to their known crystallographic structures reproduced the spectral features in the entire fitting range (1.0-4.2 $⿱$ ), and fitting parameters were in agreement with previously reported values (Mishra et al., 2011). Only the paths necessary to model the solid standards were used for fitting the solution standards and the unknown $\mathrm{Hg}$ samples. 
Two $\mathrm{Hg}$ species, $\mathrm{Hg}$-cysteine and $\mathrm{Hg}$-acetate, were utilized as solution-phase standards for $\mathrm{Hg}$ XAS analyses. First, an aqueous $\mathrm{Hg}^{2+}$ standard was prepared from high-purity $5 \mathrm{mM} \mathrm{Hg}^{2+}$ in $5 \% \mathrm{HNO}_{3}$ and was then adjusted to $\mathrm{pH} 2.0 \pm 0.1$ for measurement by adding appropriate amounts of $5 \mathrm{M} \mathrm{NaOH}$. A Hg-cysteine standard was prepared by adding cysteine to the aqueous $\mathrm{Hg}^{2+}$ standard to achieve a $\mathrm{Hg}$ :ligand ratio of 1:100. The $\mathrm{pH}$ of the $\mathrm{Hg}$-cysteine standard was adjusted to $5.0 \pm 0.1$ by adding appropriate amounts of $1 \mathrm{M}$ or $5 \mathrm{M} \mathrm{NaOH}$. A Hg-acetate standard was prepared by adding mercuric acetate salt to milliQ water and adjusting the $\mathrm{pH}$ to $5.0 \pm 0.1$ by adding appropriate amounts of $1 \mathrm{M}$ or $5 \mathrm{M} \mathrm{NaOH}$.

Sulfur K-edge XANES spectra for biomass and FA samples were acquired at sector 9BM of the Advanced Photon Source at Argonne National Laboratory using Lytle detector in fluorescence detection mode. At 9-BM, the signal from higher order harmonics was removed by detuning the monochromator to $70 \%$ of maximum beam flux at $2472.0 \mathrm{eV}$. Energy calibration was performed by setting the first peak in the spectrum of sodium thiosulfate salt $\left(\mathrm{Na}_{2} \mathrm{~S}_{2} \mathrm{O}_{3}\right)$ to $2469.2 \mathrm{eV}$. XANES spectra were measured between 2450 and $2500 \mathrm{eV}$. Step sizes in the nearedge region (2467-2482 eV) were $0.08 \mathrm{eV}$, and $0.2 \mathrm{eV}$ in pre- and post- edge regions, respectively. Samples were smeared on carbon tape and the data were collected under a He atmosphere.

For this study, sulfur species are divided into three main categories and referred to as reduced S (below $2472 \mathrm{eV}$ ), sulfoxide $\mathrm{S}$ (near $2473.5 \mathrm{eV}$ ), and oxidized S (above $2476.5 \mathrm{eV}$ ). Accordingly, three commercially-supplied (Sigma Aldrich) S standards, cysteine, dimethyl sulfoxide (DMSO), and sodium dodecyl sulfate (NaDS), were used to fingerprint S speciation. S standards were mixed with a dry powder of polyacrylic acid (PAA) to achieve a mixture containing $\sim 1 \%$ total $\mathrm{S}$ by mass. To perform $\mathrm{S}$ XANES measurements, a thin layer of a PAA-S 
standard mixture was smeared on a carbon tape. All standards were prepared within 12 hours of analysis.

To prepare $\mathrm{Hg}$ XAS samples, FA was reacted with $\mathrm{Hg}$ by diluting a commerciallysupplied $1000 \mathrm{mg} \mathrm{L}^{-1} \mathrm{Hg}$ standard with a pH-adjusted $50 \mathrm{mg} \mathrm{L}^{-1}$ FA stock solution prepared in $0.1 \mathrm{M} \mathrm{NaClO}_{4}$. The $\log$ molalities of $\mathrm{Hg}$ investigated were -4.30 and -3.60 at both $\mathrm{pH} 4.00 \pm$ 0.10 and $8.00 \pm 0.10$ for each $\mathrm{Hg}$ concentration. S. oneidensis MR-1 biomass was also reacted with $\mathrm{Hg}$ in the presence and absence of FA to ascertain possible effects of FA on the $\mathrm{Hg}$ binding environment on the bacterial cell envelopes. Biomass was collected from the experiments with a $\log$ molality of $\mathrm{Hg}$ of $-5.30, \mathrm{pH}$ values of $4.00 \pm 0.10$ or $8.00 \pm 0.10$, and $50 \mathrm{mg} \mathrm{L}^{-1} \mathrm{FA}$. Samples were loaded into slotted plexiglas holders that were subsequently covered with Kapton tape with a Kapton film sandwiched in between the tape and plexiglass to avoid direct contact of the sample with the tape adhesive. Samples were refrigerated until data collection. All measurements were conducted within 48 hours of sample preparation.

The data were analyzed by using the methods described in the UWXAFS package (Stern et al., 1995). Energy calibration between different scans was maintained by measuring $\mathrm{Hg} / \mathrm{Sn}$ amalgam on the reference chamber concurrently with the fluorescence measurements of the biomass-bound $\mathrm{Hg}$ samples (Harris et al., 2003). The inflection point of the $\mathrm{Hg} \mathrm{L}_{\mathrm{III}}$-edge (12.284 $\mathrm{KeV}$ ) was used for calibration. Data processing and fitting were done with the ATHENA and ARTEMIS programs (Ravel and Newville, 2005). The data range used for Fourier transformation of the $k$-space data was $2.0-9.5 \AA^{-1}$. The Hanning window function was used with $\mathrm{dk}=1.0 \AA^{-1}$. Fitting of each spectrum was performed in $r$-space, at 1.2-3.2 $\AA$, with multiple $k$ weighting $\left(k^{1}, k^{2}, k^{3}\right)$ unless otherwise stated. Lower $\chi_{v}{ }^{2}$ (reduced chi square) was used as the criterion for inclusion of an additional shell in the shell-by-shell EXAFS fitting procedure. 


\section{Partition coefficient calculations}

To compare the $\mathrm{Hg}$ binding behavior in the presence and absence of FA, we calculated the apparent partition coefficients, $K_{d}$, for each experimental condition. $K_{d}$ values were calculated by plotting the concentration of adsorbed $\mathrm{Hg}$ ( $\mathrm{Hg}$ lost from the experiment due to binding to bacterial cells and/or FA) on the $\mathrm{y}$-axis and the concentration of $\mathrm{Hg}$ remaining in solution on the $\mathrm{x}$-axis for each data point collected in the adsorption experiments, considering only data for one bacterial species, $\mathrm{pH}$ condition, and FA condition as a function of initial $\mathrm{Hg}$ concentration at a time. The following equation was then used to calculate the $K_{d}$ values:

$$
\mathrm{K}_{\mathrm{d}}=\frac{[\mathrm{Hg}] \text { adsorbed }}{[\mathrm{Hg}] \text { remaining in solution }}
$$

where $\mathrm{K}_{\mathrm{d}}$ is the partition coefficient and the square brackets represent concentrations in mol L ${ }^{-1}$. A best-fit line (Figure S1) was calculated for the data and the line was forced through the intersection $(0,0)$ because if no $\mathrm{Hg}$ is added to the experiment then there would be a concentration of 0 for the amount of $\mathrm{Hg}$ adsorbed and of 0 for the $\mathrm{Hg}$ remaining in solution. The slope of the best-fit line then represents the $K_{d}$ value for the dataset. $2 \sigma$ uncertainties associated with each $\mathrm{K}_{\mathrm{d}}$ value were estimated by determining the range of best-fit line slopes that would envelope approximately $95 \%$ of the data between them for each dataset.

\section{Adsorption experiments}

\section{Results and Discussion}

Consistent with previous studies of $\mathrm{Hg}$ adsorption onto bacteria (Daughney et al., 2002; Dunham-Cheatham et al., 2014), we observed extensive adsorption of $\mathrm{Hg}$ onto the bacterial species studied in the absence of FA, with the extent of adsorption relatively independent of $\mathrm{pH}$ between $\mathrm{pH} 4$ and 8 (Figure 1, top plots). For example, approximately $77 \%$ of the $\mathrm{Hg}$ in a $2 \mathrm{mg}$

$\mathrm{L}^{-1} \mathrm{Hg}$ solution adsorbs at $\mathrm{pH} 4$ onto $0.2 \mathrm{~g} \mathrm{~L}^{-1}$ S. oneidensis MR-1, while approximately $75 \%$ 
adsorbs at $\mathrm{pH}$ 8. The presence of FA significantly decreases the concentration of $\mathrm{Hg}$ that adsorbs onto cell envelopes of each of the bacterial species and at each of the $\mathrm{pH}$ conditions studied (Figure 1, middle and bottom plots). With $50 \mathrm{mg} \mathrm{L}^{-1} \mathrm{FA}$, the extent of adsorption at $\mathrm{pH} 4$ decreases to $65 \%$, and at $\mathrm{pH} 8$ to $50 \%$. T-tests were performed to determine the statistical significance of the effect of FA in each bacterial system under each $\mathrm{pH}$ condition, and was determined to be significant relative to $0 \mathrm{mg} \mathrm{L}^{-1} \mathrm{FA}$ in all systems (average $\mathrm{p}$-value $=0.02$ ). Our experimental results also indicate that the three bacterial species studied here exhibit similar extents of $\mathrm{Hg}$ adsorption under each experimental condition, consistent with the observations from a number of previous studies (e.g. Cox et al., 1999; Yee and Fein, 2001; Borrok et al., 2005, Johnson et al., 2007). Our data suggest that as the concentration of FA increases, so does the concentration of $\mathrm{Hg}$ remaining in solution. These results indicate that FA competes with the bacterial cells for the adsorption of $\mathrm{Hg}$, and that the adsorption of $\mathrm{Hg}$ to FA results in a competitive ligand effect. As a result, less $\mathrm{Hg}$ is available for adsorption to proton-active functional groups on the bacterial cell envelope, and less $\mathrm{Hg}$ is removed from solution. These results are not surprising, as FA molecules contain sulfhydryl groups within their structure and sulfhydryl groups bind strongly with Hg (Xia et al., 1999; Hesterberg et al., 2001; Drexel et al., 2002; Haitzer et al., 2002; 2003), leading to effective competition with bacterial cell envelopes which also contain proton-active sulfhydryl functional groups (Guiné et al., 2006; Mishra et al., 2007; 2009; 2010; 2011; Pokrovsky et al., 2012; Song et al., 2012; Colombo et al., 2013; Yu et al., 2014). In our experimental systems, total FA binding sites outnumber those present on the bacteria. For example, $50 \mathrm{mg} \mathrm{L}^{-1} \mathrm{FA}$ corresponds to approximately $2.8 \times 10^{-4}$ moles of sites L ${ }^{-1}$ (Borrok and Fein, 2004), while $0.2 \mathrm{~g} \mathrm{~L}^{-1}$ B. subtilis biomass contains $4.7 \times 10^{-5}$ total moles of sites $\mathrm{L}^{-1}$. At $\mathrm{pH} 8,50 \mathrm{mg} \mathrm{L}^{-1} \mathrm{FA}$ does diminish the extent of $\mathrm{Hg}$ adsorption, but only from 
approximately $75 \%$ (with no FA present) to $50 \%$. Although the total number of binding sites associated with FA is greater than the total number of binding sites associated with bacterial biomass, the concentration of high-affinity sites on FA is lower than on bacteria (Rao et al., 2014). Thus given equal site concentrations, bacterial binding of $\mathrm{Hg}$ would dominate the competition with FA due to the higher concentration of higher-affinity thiol binding sites.

The calculated $K_{d}$ values, presented in Figure 2, for the three bacterial species are similar to each other and do not vary systematically between bacterial species. Additionally, the calculated $\mathrm{K}_{\mathrm{d}}$ values for the $25 \mathrm{mg} \mathrm{L}^{-1} \mathrm{FA}$ and $50 \mathrm{mg} \mathrm{L}^{-1} \mathrm{FA}$ data are not significantly different under the same $\mathrm{pH}$ conditions. The calculated $\mathrm{K}_{\mathrm{d}}$ values do change systematically with $\mathrm{pH}$, with values decreasing with increasing $\mathrm{pH}$ when FA is present; the same trend is not observed in the absence of FA. When comparing the FA-free and FA-bearing systems for one bacterial species under the same $\mathrm{pH}$ conditions, the $\mathrm{K}_{\mathrm{d}}$ value for the FA-free system is significantly higher than the FA-bearing system in a majority of cases studied. These results suggest that the addition of FA to the experimental system decreases the amount of $\mathrm{Hg}$ removed from the solution relative to the FA-free system. This general conclusion is supported by our S XANES data, which demonstrate that the FA contains a wide range of $\mathrm{S}$ moieties while the bacterial biomass is dominated by a single thiol-type S moiety.

\section{Hg XANES and EXAFS}

To probe the effect of FA on $\mathrm{Hg}$ binding mechanisms with bacterial biomass, we examined $\mathrm{Hg}$-biomass binding at $\mathrm{pH} 4$ and 8 in the presence and absence of a stoichiometric excess of FA ( $1 \mathrm{mg} \mathrm{L}^{-1} \mathrm{Hg}$ and $\left.50 \mathrm{mg} \mathrm{L}^{-1} \mathrm{FA}\right)$ using $\mathrm{Hg} \mathrm{L}_{\mathrm{III}}$ edge XANES and EXAFS. For the XAS studies, S. oneidensis MR-1 was chosen to represent the bacterial species used in this study. 
Figure 3 shows a comparison between Hg XANES for Hg bound : 1) to FA and to S. oneidensis MR-1 biomass at $\mathrm{pH} 4,2$ ) to $S$. oneidensis MR-1 biomass in the presence and absence of FA at $\mathrm{pH} 4,3$ ) to S. oneidensis MR-1 biomass in the presence and absence of FA at $\mathrm{pH} 8$, and 4) to cysteine, and to acetate. $\mathrm{Hg}$ XANES data indicate that $\mathrm{Hg}$ is complexed with thiol groups in each of the Hg-biomass samples. Spectral features supporting this conclusion are the small pre-edge peak and the slight dip at $12300 \mathrm{eV}$ in the Hg-biomass XANES data similar to that present in the Hg-cysteine data. This finding is consistent with a previous study which showed $\mathrm{Hg}$ binding with sulfhydryl groups on B. subtilis cell envelopes under similar experimental conditions (Mishra et al., 2011). To understand these subtle differences in XANES, a linear combination fitting of the first derivative of the Hg-FA XANES data was performed which resulted in contributions of approximately $90 \%$ from $\mathrm{Hg}$-cysteine binding and approximately $10 \%$ from $\mathrm{Hg}$-carboxyl binding (Figure 4a). The first derivative of the Hg-biomass XANES data matched the first derivative of the Hg-cysteine standard, confirming that all of the $\mathrm{Hg}$ in the biomass samples was bound to thiol sites. XANES spectra of $\mathrm{Hg}$ reacted with S. oneidensis MR-1 biomass in the presence and absence of $\mathrm{FA}$ at $\mathrm{pH} 4$ and 8 are reproducible, confirming that the binding mechanism of $\mathrm{Hg}$ with S. oneidensis MR-1 biomass does not change appreciably in the presence of FA.

Hg EXAFS results are consistent with the Hg XANES results described above. Differences between the coordination environments of $\mathrm{Hg}$-FA and Hg-biomass are more pronounced in the $\mathrm{k}^{2} \bullet \chi(\mathrm{k})$ EXAFS data (Figure 5) than in the XANES data. The low signal to noise ratio in the aqueous Hg-FA data does not allow for a meaningful Fourier Transform (FT) of the Hg-FA EXAFS data. EXAFS $\mathrm{k}^{2} \chi(\mathrm{k})$ and FT data between FA-bearing and FA-free $\mathrm{Hg}_{-}$ biomass samples are similar (Figure 5), validating the Hg XANES results. Figure $4 \mathrm{~b}$ shows a 
comparison between the FT Hg EXAFS data for Hg bound to $S$. oneidensis MR-1 biomass in the presence and absence of FA at both $\mathrm{pH} 4$ and 8 and their corresponding EXAFS fits. EXAFS fitting parameters are shown in Table S1. It is worth pointing out that although the Hg-cysteine standard yielded a bond distance of $2.32 \AA$, the Hg-biomass samples at $\mathrm{pH} 4$ and 8 both had a bond distance of $2.35 \AA$. This should not be considered a discrepancy because Hg-S distances can vary from 2.32 to $2.36 \mathrm{~A}$ for $\mathrm{Hg}(\mathrm{SR})_{2}$ complexes (Manceau, and Nagy, 2008). Similarly, $\mathrm{Hg}-\mathrm{S}$ distances can range from 2.40 to $2.51 \mathrm{~A}$ for $\mathrm{Hg}(\mathrm{SR})_{3}$ complexes, and $2.50-2.61 \mathrm{~A}$ for $\mathrm{Hg}(\mathrm{SR})_{4}$ complexes. It has also been shown that $\mathrm{Hg}-\mathrm{S}$ distances for $\mathrm{Hg}$ complexed with bacterial biomass can range from $2.32 \AA$ to $2.51 \AA$, depending on the $\mathrm{Hg}$ :biomass ratio and the species of bacteria (Mishra et al., 2014).

Taken together, the Hg XANES and EXAFS spectroscopic results indicate that Hg binds predominantly to the high-affinity thiol groups on bacterial cell envelopes in the presence and absence of FA. Hg binding mechanisms with the bacterial biomass do not change in the presence of FA, ruling out the possibility of the formation of ternary complexes under the conditions studied. Additionally, Hg XAS results show that $\mathrm{pH}$ does not affect the adsorption mechanism of $\mathrm{Hg}$ onto biomass in the presence of FA, which is consistent with the similar extent of $\mathrm{Hg}$ adsorption as a function of $\mathrm{pH}$ described above. However, it is important to note that $\mathrm{Hg}$ binding mechanisms with bacterial biomass may be affected by FA at high $\mathrm{Hg}$ loadings, where $\mathrm{Hg}$ is primarily bound to biomass via more abundant, lower-affinity carboxyl functional groups (Mishra et al., 2010). Hg XAS results suggest that sulfhydryl functional groups on S. oneidensis MR-1 cell envelopes out-compete sulfhydryl functional groups in FA for Hg binding. In other words, on average $\mathrm{Hg}$ binding to FA appears weaker than $\mathrm{Hg}$ binding to bacterial biomass. 
S XANES spectroscopy was conducted to identify the differences in complexation behavior of $\mathrm{Hg}$ with $\mathrm{S}$ functional groups on FA and bacterial biomass. S K-edge XANES is highly sensitive to changes in the electronic environment of the sulfur absorber (Xia et al., 1998). Although S K-edge XANES spectra were collected on a large number of standards, in this study we have divided S species into three main categories: reduced S (below $2472 \mathrm{eV}$ ), sulfoxide S (near $2473.5 \mathrm{eV}$ ), and oxidized S (above $2476.5 \mathrm{eV}$ ). The S XANES spectra for cysteine, dimethyl sulfoxide (DMSO), and sodium dodecyl sulfate (NaDS) are shown in Figure 6a. Species with very different $\mathrm{S}$ oxidation states, such as cysteine, sulfoxide, and ester sulfate, are easily resolved in the XANES spectrum. However, resolving one species from another within these three energy ranges is challenging. Reduced $\mathrm{S}$ species, including thiols, sulfides, polysulfides, and thiophenes give white-line features occurring between 2469 and $2472 \mathrm{eV}$. More extensive model libraries that include XANES spectra of organic and inorganic $\mathrm{S}$ compounds are available in the literature (Myneni, 2002; Vairavamurthy, 1998).

Speciation of S in the S. oneidensis MR-1 biomass was easily identified because the peak energy position of the S XANES measurement on the biomass overlaps with the cysteine peak position (Figure $6 \mathrm{~b}$ ). Figure $6 \mathrm{~b}$ shows the dramatic differences between the S XANES signals from the S. oneidensis MR-1 cells and from the Suwanee River FA sample. S XANES comparing FA with $S$. oneidensis MR-1 shows that nearly the entire $\mathrm{S}$ budget of the biomass is present as thiol groups, which are known to form strong bonds with Hg. However, FA has a range of reduced S (including reactive thiol) groups and a large fraction of oxidized S species, consistent with previous observations (Morra et al., 1997). Morra et al. (1997) suggest that a significant fraction of sulfur in Suwanee River FA is oxidized (in a +5 oxidation state), with smaller fractions in reduced forms. Similarly, Einsiedl et al. (2007) used S XANES to estimate 
that soil FAs contain approximately $51 \%$ oxidized $\left(\mathrm{S}^{4+}, \mathrm{S}^{5+}, \mathrm{S}^{6+}\right)$ and $49 \%$ reduced $\left(\mathrm{S}^{1-}, \mathrm{S}^{0}, \mathrm{~S}^{2+}\right)$ sulfur species. The reduced S species in these samples were dominated by thiols, thiophene and disulfide. Rao et al. (2014) quantified the concentration of thiol groups on a range of ligands, including Suwanee River natural organic matter (SR-NOM) and G. sulfurreducens-PCA, and they report a thiol concentration on SR-NOM of $0.07 \pm 0.01 \mu \mathrm{M}$ for a SR-NOM suspension of 100 $\mathrm{mg} \mathrm{L}^{-1}$, and a concentration of thiol on $G$. sulfurreducens-PCA of $0.34 \pm 0.05 \mu \mathrm{M}$ for a bacterial suspension of $10^{13}$ cells $\mathrm{L}^{-1}$. However, there is some disagreement about the concentration of sulfhydryl sites within NOM and bacterial cell envelopes, and the values reported for thiol concentrations by Joe-Wong et al. (2012) and by Yu et al. (2014) are significantly higher than those reported by Rao et al. (2014). Using the values for thiol concentrations reported by JoeWong et al. (2012) to calculate the concentration of thiols on FA $\left(<2 \mu \mathrm{M}\right.$ per $\left.25 \mathrm{mg} \mathrm{L}^{-1} \mathrm{FA}\right)$ and B. subtilis (23.68 $\pm 2.11 \mu \mathrm{M}$ per g cell) yields a thiol concentration of $<4 \mu \mathrm{M}$ on FA (under the 50 mg $\mathrm{L}^{-1} \mathrm{FA}$ condition) and $4.7 \mu \mathrm{M}$ on $B$. subtilis in our experiments. The experimental $\mathrm{Hg}$ concentration range of our experiments was 0.5 to $10 \mu \mathrm{M}$, suggesting that there are sufficient numbers of high-affinity thiol sites to bind all of the $\mathrm{Hg}$ under the low $\mathrm{Hg}$ concentration conditions studied, and that most of the $\mathrm{Hg}$ can be bound to thiol groups under the higher $\mathrm{Hg}$ concentration conditions studied. Any additional Hg adsorption beyond the combined total thiol concentrations from FA and bacterial biomass is caused by Hg binding onto the more abundant, lower-affinity functional groups. These calculations demonstrate that bacteria and NOM may exhibit roughly similar thiol site concentrations in environmental systems, so under low metal loading conditions, the speciation and distribution of metals bound to NOM or bacteria may be quite sensitive to their relative concentrations and to the specific make-up of thiol sites within 
each sorbent. A detailed study of the reactivity and stability of $\mathrm{Hg}$ with FA and bacterial biomass thiol sites is beyond the scope of this study.

The experimental results presented here suggest that bacterial cell envelope functional groups and FA functional groups exhibit different binding affinities for $\mathrm{Hg}$ under the experimental conditions. $\mathrm{Hg}$ binding onto the bacterial cell envelopes is extensive, and although Hg binds strongly with FA, especially with the sulfhydryl groups present within FA (Xia et al., 1999; Hesterberg et al., 2001; Drexel et al., 2002; Haitzer et al., 2002; 2003), the presence of even up to $50 \mathrm{ppm}$ FA with only $0.2 \mathrm{~g}$ (wet mass) $\mathrm{L}^{-1}$ of bacteria does not cause the speciation of $\mathrm{Hg}$ to be dominated by the FA. The results suggest that there is a possibility for competition between the bacterial and FA binding sites for the available $\mathrm{Hg}$.

\section{Conclusions}

The results from this study show that the presence of FA decreases the extent of $\mathrm{Hg}$ adsorption onto three different bacterial species through competitive binding of the $\mathrm{Hg}$. The presence of the FA does not change the binding environment of $\mathrm{Hg}$ on the bacteria, indicating a lack of ternary complexation between the $\mathrm{Hg}$, the FA, and the bacteria under the conditions studied. The binding of $\mathrm{Hg}$ to both the bacteria and the FA under the experimental conditions is dominated by sulfhydryl binding to both ligands, and the similarities between the binding environments likely results in the competitive balance between them. We used the experimental results to calculate partition coefficients for the binding of $\mathrm{Hg}$ to bacteria and FA, which can be used to estimate the distribution and speciation of $\mathrm{Hg}$ in bacteria- and FA-bearing geologic systems under conditions comparable to our experimental conditions. 


\section{Acknowledgements}

Funding for this research was provided by a U.S. Department of Energy, Subsurface Biogeochemistry Research (SBR) grant. The experiments and analyses were performed at the Center for Environmental Science \& Technology, University of Notre Dame. XAS measurements were obtained at the MRCAT-10-ID Beamline at the Advanced Photon Source (APS), Argonne National Laboratory. BM was supported by the Argonne Subsurface Scientific

Focus Area project, which is part of the SBR Program of the Office of Biological and Environmental Research (BER), U.S. DOE under contract DE-AC02-06CH11357.

Three helpful and thorough journal reviews and the comments by Associate Editor Owen Duckworth significantly improved this work and are appreciated. 


\section{$\underline{\text { Figures }}$}
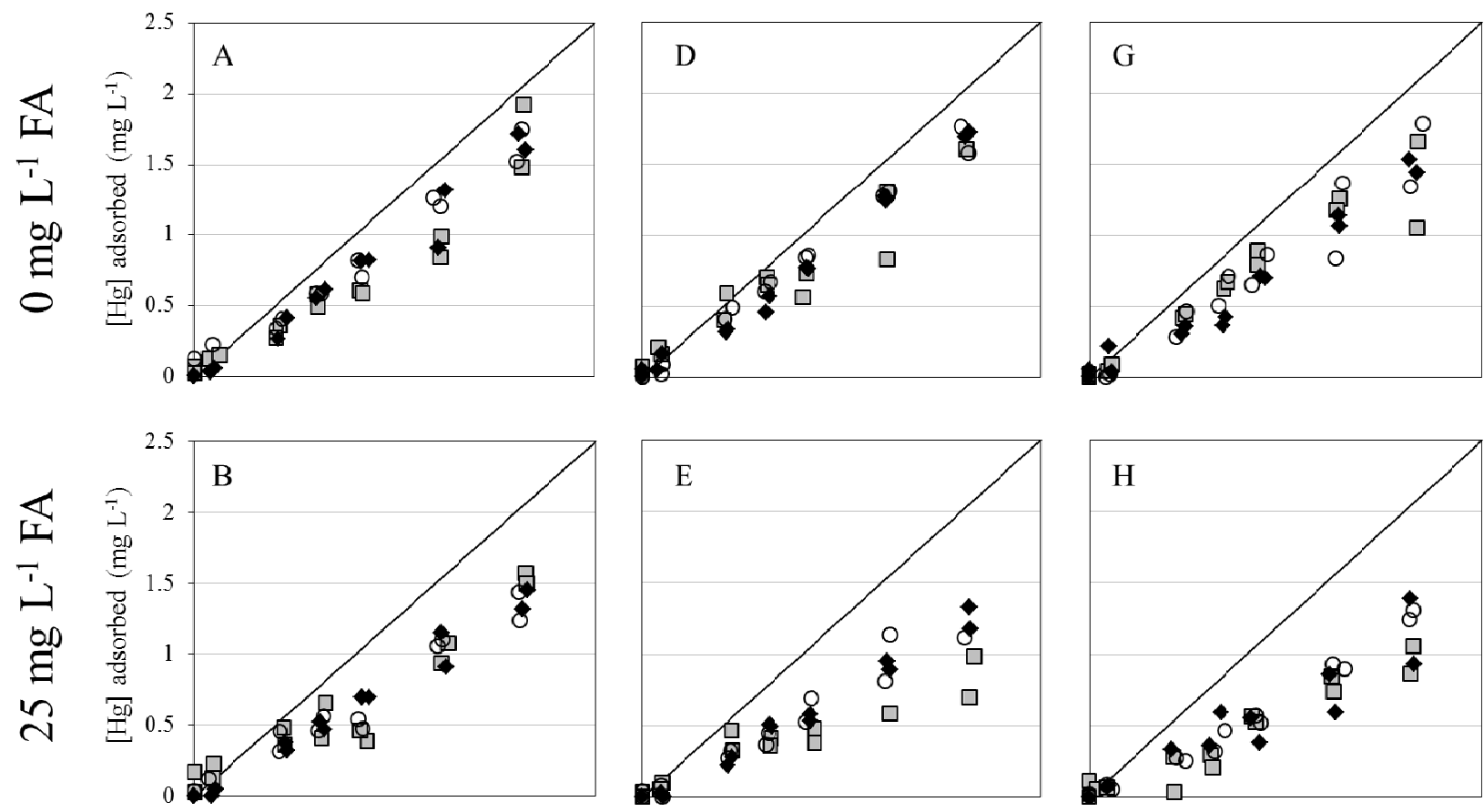

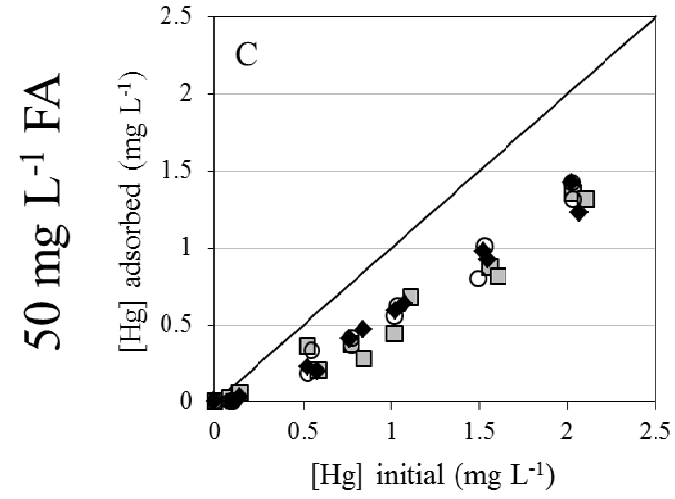

$\mathrm{pH} 4$

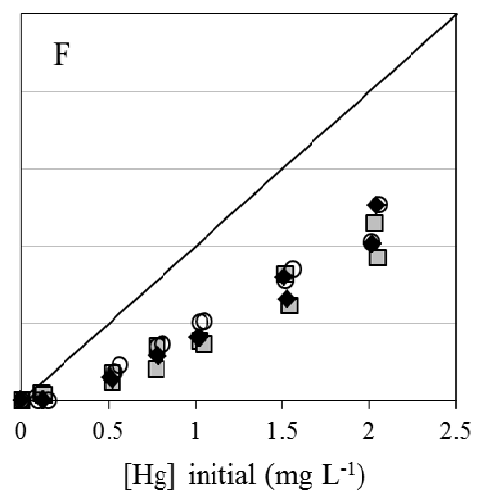

$\mathrm{pH} 6$

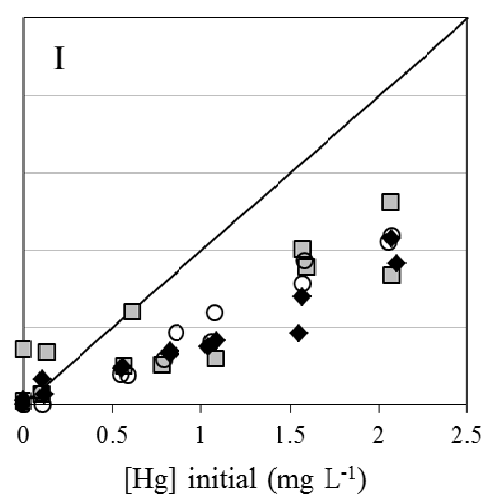

$\mathrm{pH} 8$

Figure 1: Aqueous chemistry results for $\mathrm{Hg}$ isotherms in the absence and presence of $\mathrm{FA}$ at $\mathrm{pH} 4$ (A, B, C), pH 6 (D, E, F), and pH 8 (G, H, I). Plots A, D, and G present the results for the FAfree controls, plots $\mathrm{B}, \mathrm{E}$, and $\mathrm{H}$ present the results for the $25 \mathrm{mg} \mathrm{L}^{-1} \mathrm{FA}$ experiments, and plots $\mathrm{C}$, $\mathrm{F}$, and I present the results of the $50 \mathrm{mg} \mathrm{L}^{-1} \mathrm{FA}$ experiments. B. subtilis is represented by the black-outlined, grey-filled squares, $S$. oneidensis MR-1 is represented by the solid black diamonds, and G. sulfurreducens is represented by the hollow circles. The black line on each plot represents $100 \% \mathrm{Hg}$ adsorption under each experimental condition. 

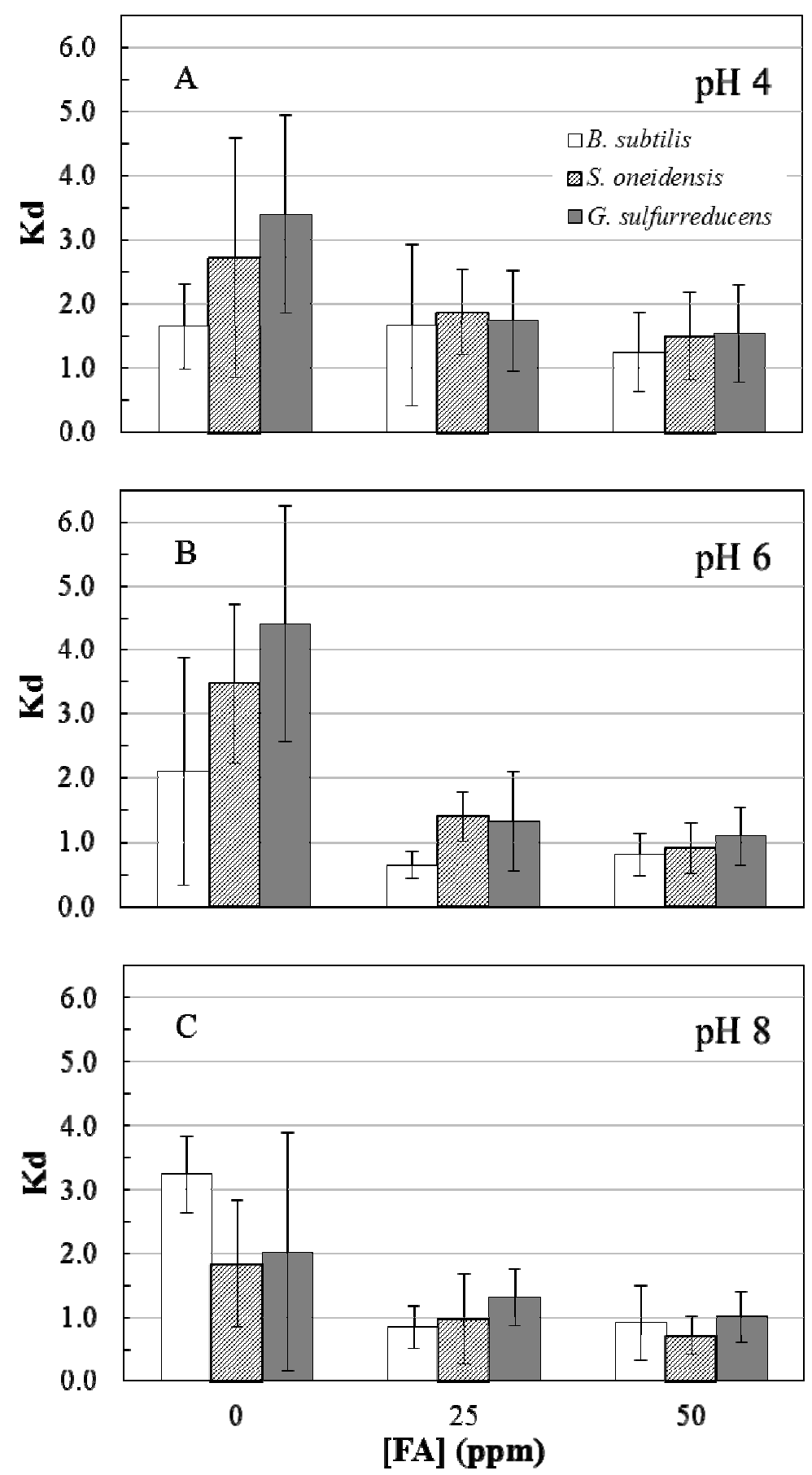

Figure 2: Calculated $\mathrm{K}_{\mathrm{d}}$ values for all $\mathrm{pH} 4$ (A), $\mathrm{pH} 6$ (B), and $\mathrm{pH} 8$ (C) fulvic acid conditions (on X-axis). B. subtilis is represented by the white bars, S. oneidensis MR-1 is represented by the hashed bars, and G. sulfurreducens is represented by the dark gray bars. Error bars represent $2 \sigma$. 


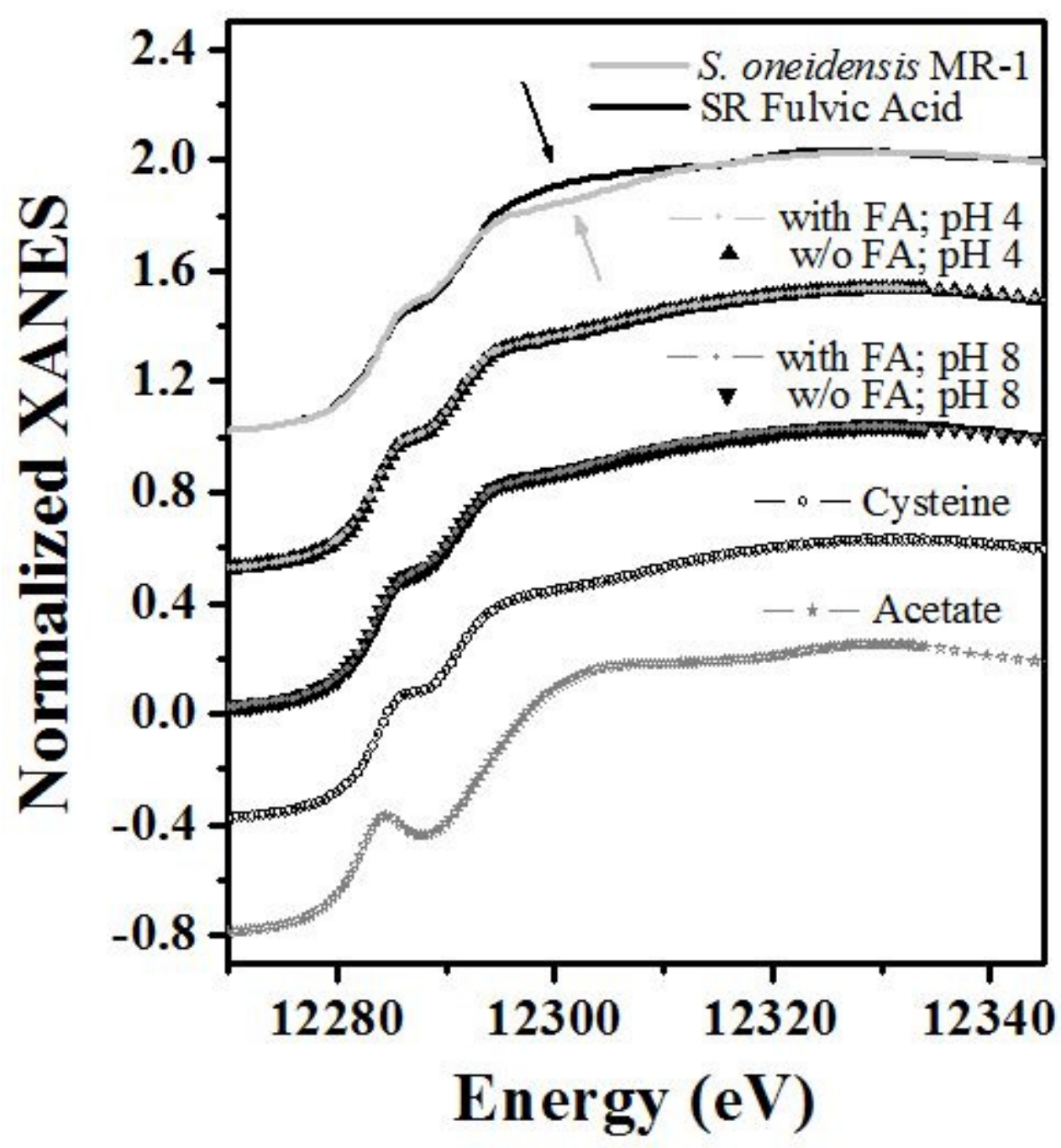

Figure 3: $\mathrm{Hg} \mathrm{L}_{\text {III }}$ edge XANES spectra of $\mathrm{Hg}$ bound to (from top to bottom) S. oneidensis MR-1 only at $\mathrm{pH} 4$, FA only at $\mathrm{pH} 4$, S. oneidensis MR-1 in the presence of 50 and $0 \mathrm{mg} \mathrm{L}^{-1} \mathrm{FA}$ at $\mathrm{pH}$ 4, S. oneidensis MR-1 in the presence of 50 and $0 \mathrm{mg} \mathrm{L}^{-1} \mathrm{FA}$ at $\mathrm{pH} 8$, cysteine only, and acetate only. 

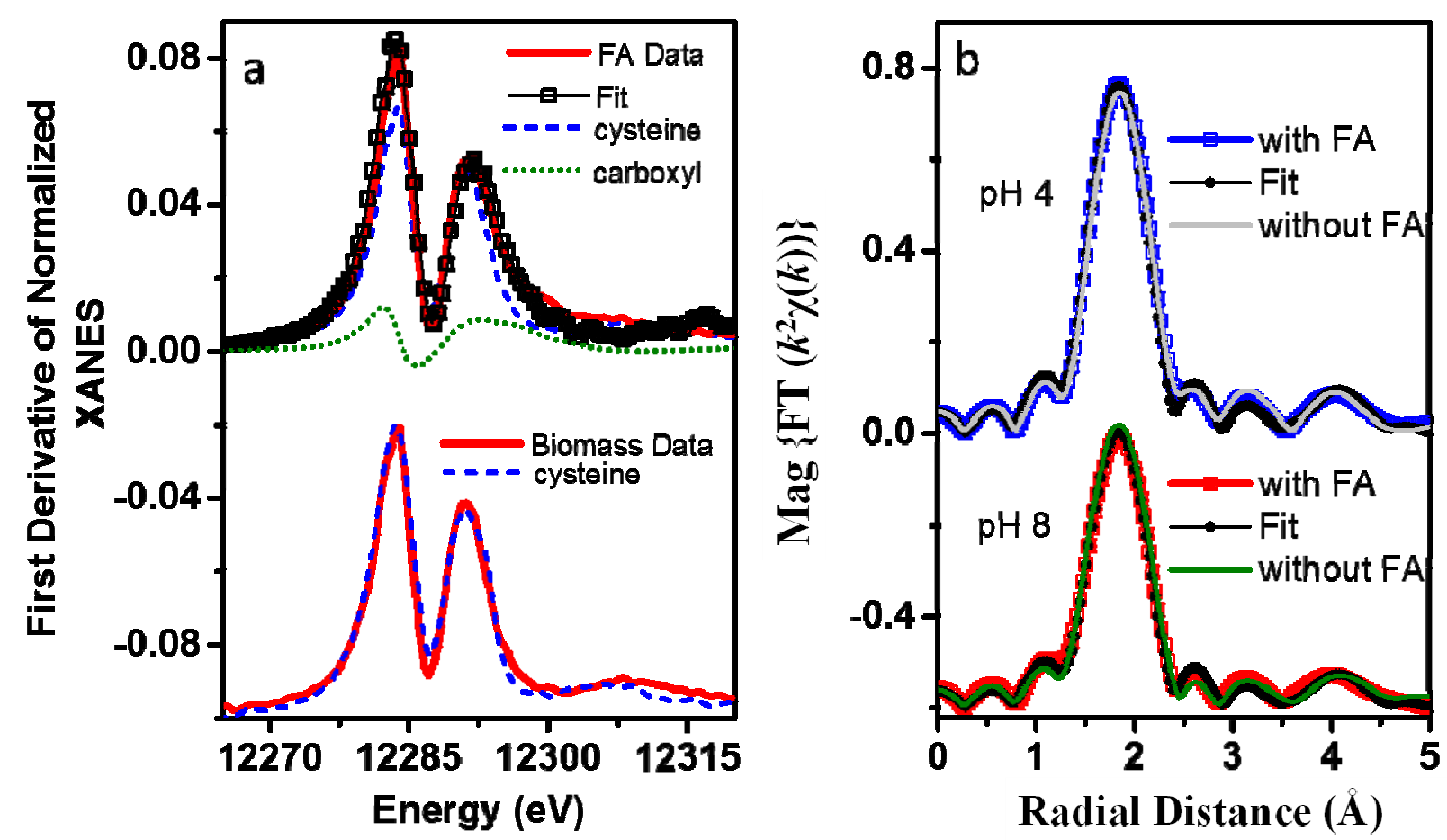

Figure 4: a) Linear combination fitting of the first derivative of the Hg-FA XANES data plotted with components. The first derivative of the $\mathrm{Hg}$-biomass data is shown with the Hg-cysteine standard only. b) EXAFS Fourier transform (FT) data of the Hg-biomass data with and without fulvic acid at $\mathrm{pH} 4$ and 8 overlaid with corresponding fits. 


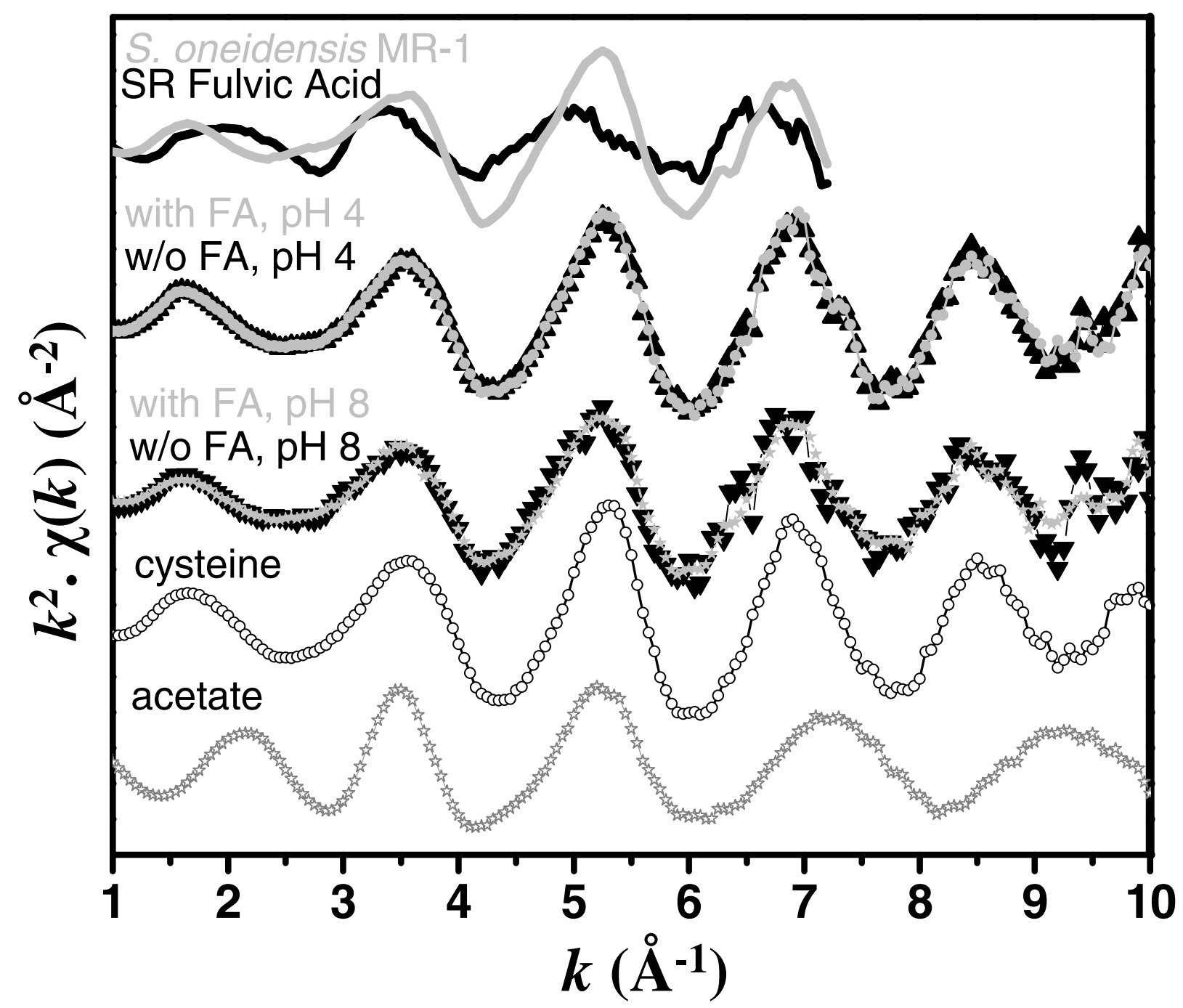

Figure 5: $\mathrm{k}^{2} \bullet \gamma(\mathrm{k})$ EXAFS data for $\mathrm{Hg}_{\mathrm{III}}$ edge EXAFS spectra of $\mathrm{Hg}$ bound to (top to bottom):

S. oneidensis MR-1 only at $\mathrm{pH} 4, \mathrm{FA}$ only at $\mathrm{pH} 4$, S. oneidensis MR-1 in the presence of 50 and $0 \mathrm{mg} \mathrm{L}^{-1} \mathrm{FA}$ at $\mathrm{pH} 4$, S. oneidensis MR-1 in the presence of 50 and $0 \mathrm{mg} \mathrm{L}^{-1} \mathrm{FA}$ at $\mathrm{pH} 8$, cysteine only, and acetate only. 

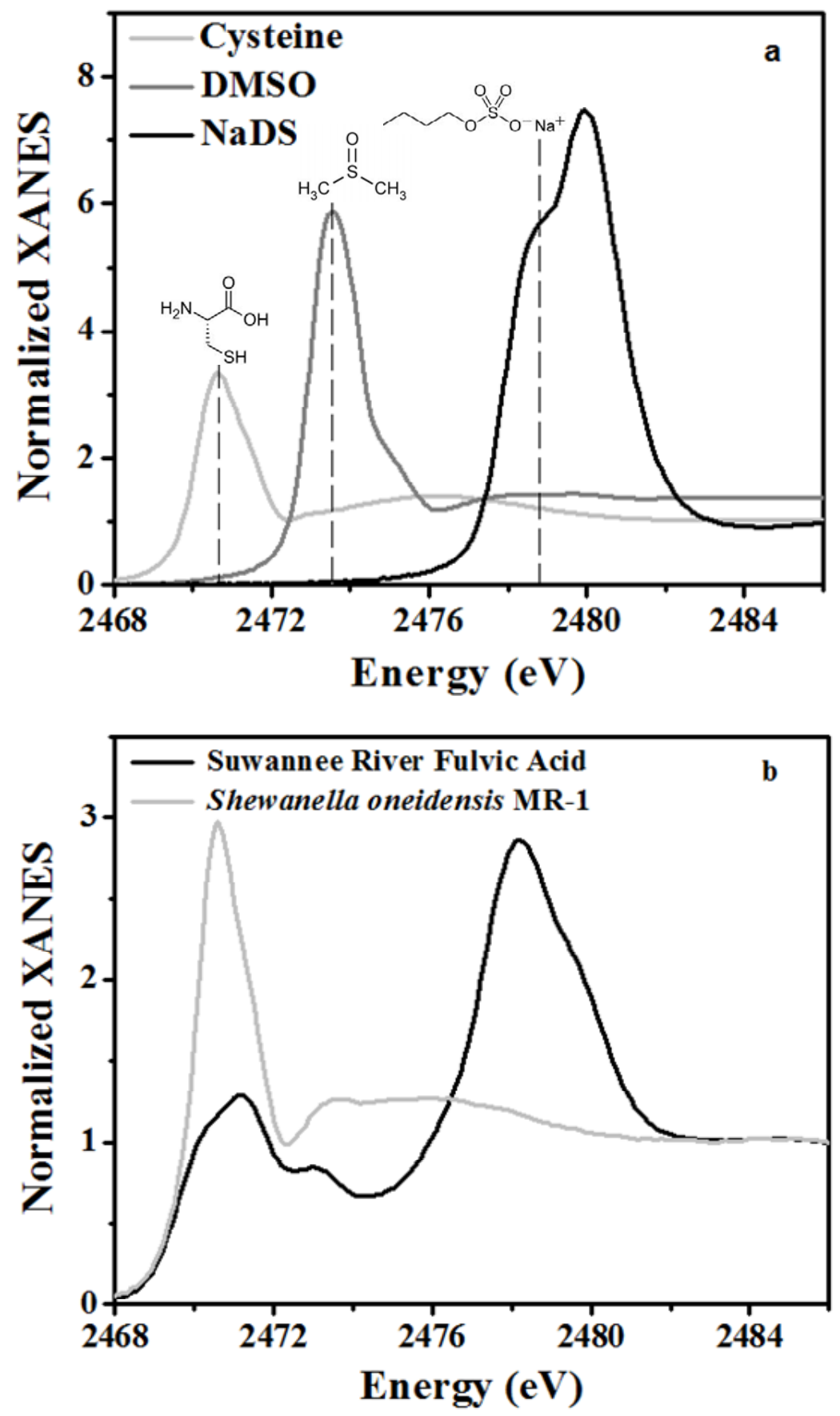

Figure 6: Sulfur K edge XANES spectra for a) cysteine, dimethyl sulfoxide (DMSO), and sodium dodecyl sulfate (NaDS), and b) S. oneidensis MR-1 biomass and Suwannee River FA. 


\section{$\underline{\text { References }}$}

Benoit J. M., Gilmour C. C., Mason R. P., and Heyes A. (1999) Sulfide Controls on Mercury Speciation and Bioavailability to Methylating Bacteria in Sediment Pore Waters. 33. 951957.

Beveridge T. J., and Murray R. G. E. (1976) Uptake and retention of metals by cell walls of Bacillus subtilis. Journal of Bacteriology. 127. 1502-1518.

Borrok D and Fein J. B. (2004) Distribution of protons and Cd between bacterial surfaces and dissolved humic substances determined through chemical equilibrium modeling. Geochimica et Cosmochimica Acta. 68. 3043-3052.

Borrok D., Turner B. F., and Fein J. B. (2005) A universal surface complexation framework for modeling proton binding onto bacterial surfaces in geologic settings. American Journal of Science. 305. 826-853.

Borrok D., Aumend K. and Fein J. B. (2007) Significance of ternary bacteria-metal-natural organic matter complexes determined through experimentation and chemical equilibrium modeling. Chemical Geology. 238. 44-62.

Colombo M. J., Ha J., Reinfelder J. R., Barkay T., Yee N. (2013) Anaerobic oxidation of $\operatorname{Hg}(0)$ and methylmercury formation by Desulfovibrio desulfuricans ND132. Geochimica et Cosmochimica Acta. 112. 166-177.

Compeau G. C., and Bartha R. (1987) Effect of salinity on mercury-methylating activity of sulfate-reducing bacteria in estuarine sediments. Applied and Environmental Microbiology. 53. 261-265.

Cox J. S., Smith D. S., Warren L. A., and Ferris F. G. (1999) Characterizing heterogeneous bacterial surface functional groups using discrete affinity spectra for proton binding. Environmental Science \& Technology. 33. 4514-4521.

Croué J.-P., Benedetti D., Violleau D., and Leenheer J. A. (2003) Characterization and Copper Binding of Humic and Nonhumic Organic Matter Isolated from the South Platte River: Evidence for the Presence of Nitrogenous Binding Sites. Environmental Science \& Technology. 37. 328-336.

Daughney C. J., Siciliano S. D., Rencz A. N., Lean D., and Fortin D. (2002) Hg(II) adsorption by bacteria: A surface complexation model and its application to shallow acidic lakes and wetlands in Kejimkujik National Park, Nova Scotia, Canada. Environmental Science \& Technology. 36. 1546-1553.

Dong W. M., Bian Y. R., Liang L. Y., and Gu B. H. (2011) Binding Constants of Mercury and Dissolved Organic Matter Determined by a Modified Ion Exchange Technique. Environmental Science \& Technology. 45. 3576-3583.

Drexel R. T., Haitzer M., Ryan J. N., Aiken G. R., and Nagy K. L. (2002) Mercury(II) Sorption to Two Florida Everglades Peats: Evidence for Strong and Weak Binding and Competition by Dissolved Organic Matter Released from the Peat. Environmental Science \& Technology. 36. 4058-4064. 
Dunham-Cheatham S., Farrell B., Mishra B., Myneni S., and Fein J. B. (2014) The effect of chloride on the adsorption of $\mathrm{Hg}$ onto three bacterial species. Chemical Geology. 373. 106114.

Einsiedl F., Hertkorn N., Wolf M., Frommberger M., Schmitt-Kopplin P., and Boris P. K. (2007) Rapid biotic molecular transformation of fulvic acids in a karst aquifer. Geochimica et Cosmochimica Acta. 71. 5474-5482.

Ephraim J. H. (1992) Heterogeneity as a concept in the interpretation of metal ion binding by humic substances. The binding of zinc by an aquatic fulvic acid. Analytica Chimica Acta. 267. 39-45.

Fein J. B., Boily J. F., Yee N., Gorman-Lewis D., and Turner B. F. (2005) Potentiometric titrations of Bacillus subtilis cells to low $\mathrm{pH}$ and a comparison of modeling approaches. Geochimica et Cosmochimica Acta. 69. 1123-1132.

Fein, J.B., 2006. Thermodynamic modeling of metal adsorption onto bacterial cell walls: current challenges. Adv. Agron. 90, 179-202.

Fortin D. and Beveridge T. J. (1997) Role of the bacterium Thiobacillus in the formation of silicates in acidic mine tailings. Chemical Geology. 141. 235-250.

Guiné V., Spadini L., Sarret G., Muris M., Delolme C., Gaudet J. P., and Martins J. M. F. (2006) Zinc sorption to three gram-negative bacteria: Combined titration, modeling, and EXAFS study. Environmental Science \& Technology. 40. 1806-1813.

Haitzer M., Aiken G. R., and Ryan J. N. (2002) Binding of Mercury(II) to Dissolved Organic Matter: The Role of the Mercury-to-DOM Concentration Ratio. Environmental Science \& Technology. 36. 3564-3570.

Haitzer M., Aiken G. R., and Ryan J. N. (2003) Binding of Mercury(II) to Aquatic Humic Substances: Influence of $\mathrm{pH}$ and Source of Humic Substances. Environmental Science \& Technology. 37. 2436-2441.

Harris, H. H., Pickering, I. J., George, G. N. (2003) The Chemical Form of Mercury in Fish.Science. 301. 1203.

Hesterberg D., Chou J. W., Hutchison K. J., and Sayers D. E. (2001) Bonding of $\mathrm{Hg}(\mathrm{II})$ to Reduced Organic Sulfur in Humic Acid as Affected by S/Hg Ratio. Environmental Science \& Technology. 35. 2741-2745.

Joe-Wong, C., Shoenfelt, E., Hauser, E.J., Crompton, N., Myneni, S.C.B. (2012) Estimation of reactive thiol concentrations in dissolved organic matter and bacterial cell membranes in aquatic systems. Environ. Sci. Technol. 46 (18), 9854-9861.

Johnson K. J., Szymanowski J. E. S., Borrok D., Huynh T. Q., and Fein J. B. (2007) Proton and metal adsorption onto bacterial consortia: Stability constants for metal-bacterial surface complexes. Chemical Geology. 239. 13-26.

Kenney J. P. L. and Fein J. B. (2011) Cell wall reactivity of acidophilic and alkaliphilic bacteria determined by potentiometric titrations and $\mathrm{Cd}$ adsorption experiments. Environmental Science \& Technology. 45. 4446-4452. 
Loux, N. T. (1998) An assessment of mercury-species-dependent binding with natural organic carbon. Chemical Speciation and Bioavailability. 10. 127-136.

Lovely, D.R. and Phillips, E.J.P. (1988) Novel mode of microbial energy metabolism: organic carbon oxidation coupled to dissimilatory reduction of iron or manganese. Applied and Environmental Microbiology. 54. 1472-1480.

Manceau A. and Nagy K. L. (2008) Relationships between $\mathrm{Hg}(\mathrm{II})-\mathrm{S}$ bond distance and $\mathrm{Hg}(\mathrm{II})$ coordination in thiolates. Dalton Transactions. 11. 1421-1425.

Martell A. E. and Smith R. M. (2001) NIST Critically selected stability constants of metal complexes, Version 6.0. NIST Standard Reference Database. 46. National Institute of Standards and Technology. Gaithersburg, MD.

McDowell W. H. (2003) Dissolved organic matter in soils - future directions and unanswered questions. Geoderma. 113. 179-186.

Mishra, B., Fein, J. B., Boyanov, M. I., Kelly, S. D., Kemner, K. M., Bunker, B. A. (2007) Comparison of Cd Binding Mechanisms by Gram-Positive, Gram-Negative and Consortia of Bacteria Using XAFS. AIP Conference proceeding. 882. 343-345.

Mishra B., Boyanov M. I., Bunker B. A., Kelly S. D., Kemner K. M., Nerenberg R., Read-Daily B.L., and Fein J. B. (2009) An X-ray absorption spectroscopy study of Cd binding onto bacterial consortia. Geochimica et Cosmochimica Acta. 73. 4311-4325.

Mishra B., Boyanov M., Bunker B. A., Kelly S. D., Kemner K. M., and Fein J. B. (2010) Highand low-affinity binding sites for $\mathrm{Cd}$ on the bacterial cell walls of Bacillus subtilis and Shewanella oneidensis. Geochimica et Cosmochimica Acta. 74. 4219-4233.

Mishra B., O’Loughlin E. J., Boyanov M. B., Kemner K. M. (2011) Binding of HgII to HighAffinity Sites on Bacteria Inhibits Reduction to $\mathrm{Hg}^{0}$ by Mixed Fe ${ }^{\mathrm{II} / \mathrm{III}}$ Phases. Environmental Science \& Technology. 45. 9597-9603.

Mishra B., Shoenfelt E., Yu Q., Yee N., Fein J. B., Myneni S.C.B. (2014) Mercury-thiol complexes on bacterial cell envelopes. Environmental Science and Technology Letters. (in revision)

Morra, M.J., Fendorf, S. E., Brown, P. D. (1997) Speciation of sulfur in humic and fulvic acids using X-ray absorption near-edge structure (XANES) spectroscopy. Geochimica et Cosmochimica Acta. 61. 683-688.

Muresan B., Pernet-Coudrier B., Cossa D., and Varrault G. (2011) Measurement and modeling of mercury complexation by dissolved organic matter isolates from freshwater and effluents of a major wastewater treatment plant. Applied Geochemistry. 26. 2057-2063.

Myneni, S. C. B. (2002) Soft X-ray spectroscopy and spectromicroscopy studies of organic molecules in the environment. Reviews in Mineralogy and Geochemistry. 49. 485-579.

Pokrovsky O.S., Pokrovski G. S., Shirokova L.S., Gonzalez A. G., Emnova E. E., Feurtet-Mazel A. (2012) Chemical and structural status of copper associated with oxygenic and anoxygenic phototrophs and heterotrophs: possible evolutionary consequences. Geobiology. 10. 130-149.

Powell K. J., Brown P. L., Byrne R. H., Gajda T., Hefter G., Sjoberg S., and Wanner H. (2005) Chemical speciation of environmentally significant heavy metals with inorganic ligands. Part 
1: The $\mathrm{Hg}^{2+}-\mathrm{Cl}^{-}, \mathrm{OH}^{-}, \mathrm{CO}_{3}{ }^{2-}, \mathrm{SO}_{4}{ }^{2-}$, and $\mathrm{PO}_{4}{ }^{3-}$ aqueous systems. Pure and Applied Chemistry. 77. 739-800.

Rao, B., Simpson, C., Lin, H., Liang, L, and B. Gu. (2014) Determination of thiol functional groups on bacteria and natural organic matter in environmental systems. Talanta. 119. 240247.

Ravel, B., Newville,M. (2005) ATHENA, ARTEMIS, HEPHAESTUS: Data analysis for X-ray absorption spectroscopy using IFEFFIT. Journal of Synchrotron Radiation. 12. 537-541.

Ravichandran M., Aiken G. R., Ryan J. N., and Reddy M. M. (1999) Inhibition of precipitation and aggregation of metacinnabar (mercuric sulfide) by dissolved organic matter isolated from the Florida Everglades. Environmental Science \& Technology. 33. 1418-1423.

Ravichandran M. (2004) Interactions between mercury and dissolved organic matter - a review. Chemosphere. 55. 319-331.

Skyllberg U., Bloom P. R., Qian J., Lin C.-M., and Bleam W. F. (2006) Complexation of Mercury(II) in Soil Organic Matter: EXAFS Evidence for Linear Two-Coordination with Reduced Sulfur Groups. Environmental Science \& Technology. 40. 4174-4180.

Segre, C. U., Leyarovsky, N. E., Chapman, L. D., Lavender, W. M., Plag, P. W., King, A. S., Kropf, A. J., Bunker, B. A., Kemner, K. M., Dutta, P., Duran, R. S., Kaduk, J. (2000) The MRCAT insertion device beamline at the Advanced Photon Source, CP521. Synchrotron Radiation Instrumentation: Eleventh U.S. National Conference; Pianetta, P., Ed.; American Institute of Physics:NewYork, 419-422.

Song Z., Kenney J. P. L., Fein J. B., Bunker B. A. (2012) An X-Ray Absorption Fine Structure study of $\mathrm{Au}$ adsorbed onto the non-metabolizing cells of two soil bacterial species. Geochimica et Cosmochimica Acta. 86. 103-117.

Stern, E. A., Newville, M., Ravel, B., Yacoby, Y., Haskel, D. (1995) The UWXAFS analysis package philosophy and details. Physica B. 209. 117-120.

Vairavamurthy, A. (1998) Using X-ray absorption to probe sulfur oxidation states in complex molecules. Spectrochimica Acta Part A: Molecular and Biomolecular Spectroscopy. 54. 2009-2017.

Westall J. C. (1982) FITEQL, A computer program for determination of chemical equilibrium constants from experimental data. Version 2.0. Report 82-02, Department of Chemistry, Oregon State University, Corvallis, OR, USA.

Wightman P. G. and Fein J. B. (2001) Ternary interactions in a humic acid-Cd-bacteria system. Chemical Geology. 180. 55-65.

Winfrey M. R. and Rudd J. W. M. (1990) Environmental factors affecting the formation of methylmercury in low pH lakes. Environmental Toxicology and Chemistry. 9. 853-869.

Xia K., Skyllberg U. L., Bleam W. F., Bloom P. R., Nater E. A., and Helmke P. A. (1999) X-ray Absorption Spectroscopic Evidence for the Complexation of $\mathrm{Hg}(\mathrm{II})$ by Reduced Sulfur in Soil Humic Substances. Environmental Science \& Technology. 33. 257-261. 
Xia K., Weesner, F., Bleam W.F., Helmke P.A., Bloom P.R., Skyllberg U.L. (1998) XANES Studies of Oxidation States of Sulfur in Aquatic and Soil Humic Substances. Soil Science Society of America Journal. 62. 124-1246.

Yee N. and Fein J. B. (2001) Cd adsorption onto bacterial surfaces: A universal adsorption edge? Geochimica et Cosmochimica Acta. 65. 2037.

Yu, Q., Szymanowski, J., Myneni S.C.B., and Fein, J.B. (2014) Characterization of sulfhydryl sites within bacterial cell envelopes using selective site-blocking and potentiometric titrations. Chemical Geology 373, 50-58. 